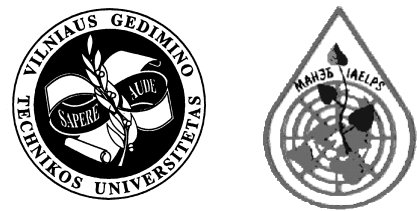

ISSN $1648-6897$

JOURNAL OF ENVIRONMENTAL ENGINEERING AND LANDSCAPE MANAGEMENT

http:/www.vtu.lt/english/editions

2005, Vol XIII, No 2, 57-64

\title{
EXPERIMENTAL INVESTIGATION OF PARTICLE CONCENTRATION USING MASS AND OPTICAL METHODS
}

\author{
Pranas Baltrẻnas, Mindaugas Kvasauskas
}

\author{
Dept of Environmental Protection, Vilnius Gediminas Technical University, \\ Sauletekio al. 11, LT-10223 Vilnius-40, Lithuania.E-mail: aak@ap.vtu.lt
}

Received 3 Mar 2005; accepted 10 Mar 2005

\begin{abstract}
Devices of various design and measuring methods are applied for determining particle matter (PM) concentration. Therefore, it is important to know measuring precision of different measuring devices. Measurements were carried out by a recognized and widely used mass as well as the optical method. Materials commonly occurring in technological processes were used for investigation: particles of wood, cement, quartz sand and metal from polishing processes, clay and charcoal particles. Besides, the concentration of PM at one of the most bustling crossroads of Vilnius city was measured to estimate and compare the results of the mentioned methods and evaluate their suitability for measuring very low concentrations of PM. Measuring results of PM concentration are compared and estimated in this work, and coefficients, showing measuring differences among different devices and methods, are given and measuring errors are rated.
\end{abstract}

Keywords: mass method, optical method, particle matter (PM).

\section{Introduction}

There are three separate parts for assessing air quality in Lithuania - Vilnius, Kaunas and a territory without Vilnius and Kaunas cities. Automatic stations work in Lithuania's territory which give information about pollution with the main pollutants, including particle matter $\mathrm{PM}_{10}$ (small particles the diameter of witch is not bigger than $10 \mu \mathrm{m})$. Particles of this size stay longer in the air and are more harmful to human health because they can get into lungs and accumulate in aircells.

It is very difficult to measure the concentration of these particles because of their small size $[1,2]$. The $\mathrm{PM}_{10}$ concentration in ambient air is influenced by stationary pollution sources of industry and energetic objects, all kinds of transport, as well as natural processes in the environment (particles raised by wind, volcanic outbreaks, etc) [2-5]. It is essential that measuring results correspond to the basic method prescribed in the EU directive 1999/30/EB.

In Vilnius Gediminas Technical University comparative investigation of PM concentration was performed with a new optical meter Microdust pro (Casella), and the measuring results obtained by optical and mass methods were compared.
The aim of the work was to measure PM concentrations with different devices in natural conditions, to compare and analyze the measuring results, to rate coefficients showing measuring differences among different devices and methods, to rate measuring errors.

\section{Methodology}

To estimate measuring the results and rate coefficients subject to different materials (hard particles) and air flow, particles of different materials were chosen for the investigation. Materials commonly occurring in technological processes were used for the investigation: particles of wood, cement, quartz sand and metal from polishing processes, clay and charcoal particles.

Charcoal was prepared heating wood at $200{ }^{\circ} \mathrm{C}$ for 4 hours, and later it was pulverized. Before measurements these materials must be prepared respectively: not wet and clean. All the particles were dried at $80^{\circ} \mathrm{C}$ temperature, and then left for 24 hours at $24-26^{\circ} \mathrm{C}$ temperature. PM humidity did not exceed $65 \%$.

During measurements attempts were made to maintain the primary particle (substance) and ambient conditions [3]. During the experiment the ambient temperature varied from $24,4{ }^{\circ} \mathrm{C}$ to $25,9^{\circ} \mathrm{C}$, while the relative humidity was $58 \%$. 
Concentration of different PM-type telltale samples was determined in the air sampled for $2 \mathrm{~min}$ for wood PM emissions, for $3 \mathrm{~min}$ - for emissions of quartz sand, cement, clay and charcoal, and for $5 \mathrm{~min}$ - for metal PM emissions.

Concentration of particles was measured by two methods: optical and mass (gravimetrical) methods. To compare the measuring results of devices and rate coefficients showing measuring differences among different devices, these devices were connected in series to an aspiration system (Fig 1).

Microdust pro has the highest level to measure the size of breathed particles. Microdust pro has 4 measuring levels:

$>$ from 0,001 to $2,5 \mathrm{mg} / \mathrm{m}^{3}$;

$>$ from 0,01 to $25,0 \mathrm{mg} / \mathrm{m}^{3}$;

$>$ from 0,1 to $250,0 \mathrm{mg} / \mathrm{m}^{3}$;

$>$ from 1,0 to $2500 \mathrm{mg} / \mathrm{m}^{3}$.

Light is collected when sampled air flow is clean. When PM gets into a measuring cell, light is scattered (at $12-20^{\circ}$ angle) to a collector.

Course of work. Particles are poured into a device of air and dust mixture, it is heat-sealed and a fan is launched inside the device (Fig 2). After launching the fan, air flow forms which raises the particles inside and scatters them throughout the device. When dustiness is steady, an aspirator is switched on which pumps air flow through the measuring cell of the optical meter Microdust pro and filter used for measuring particle concentration by the mass method.

Particles of each material were sampled at a differ-

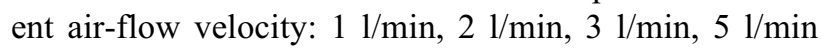

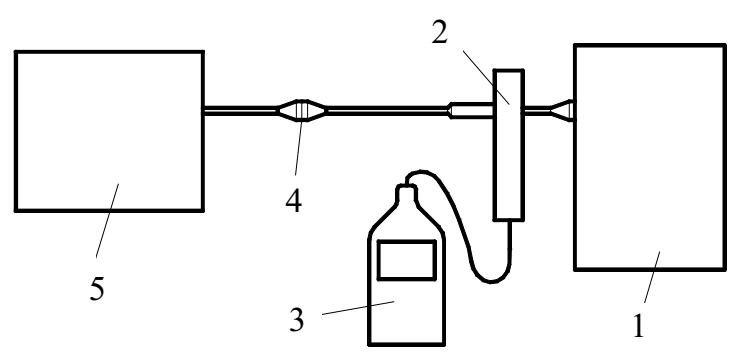

Fig 1. Scheme of measuring stand: 1 - device of air and dust mixture, 2 - probe of optical meter Microdust pro, 3 - optical meter Microdust pro, 4 - filter holder, 5 - aspirator

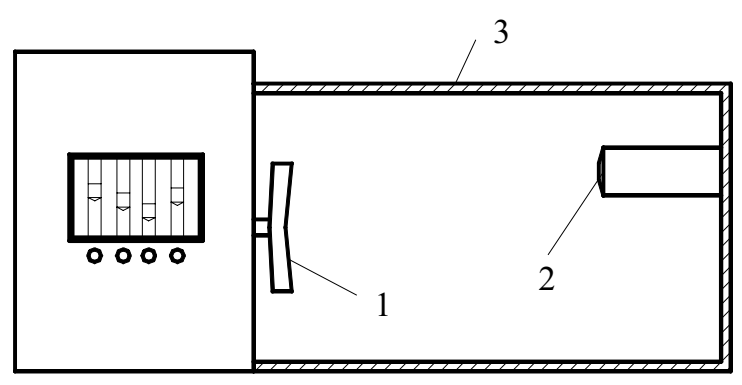

Fig 2. Device of air and dust mixture: 1 - fan, 2 - illumination, 3 - body and $10 \mathrm{l} / \mathrm{min}$. Because of gravitation particles set down little, their concentration, even marginally, declines [6, 7]. To avoid measuring inaccuracy we wait for particles set down after each measuring, then all the particles are gathered in one place in front of the fan, and it is switched on again. Three measurements are made with the particles of the same material at the same dusty airflow velocity. Average values of the measurements are written down on the table of measurement results $[8,9]$.

After sampling one material, the device must be cleaned thoroughly, and only then the particles of another material are poured.

After each measuring of particle concentration, before measuring the particle concentration of another material, hoses are scavenged by a strong air flow. An optical measurement meter must be calibrated newly, conditional zero must be set.

Measuring methodology at roadsides. Air pollution at any time is not steady. Its fluctuations depend on exhausted pollutant amount from a pollution source, atmospheric conditions and other factors. The number of cars and the wind also have a great influence.

Before starting air pollution measurements, the following conditions are required:

- air temperature must be $5{ }^{\circ} \mathrm{C}$ and higher;

- relative air humidity must be less than $80 \%$.

When measuring the level of air pollution, it is essential to know that samples are taken at a distance of 1,5-3 $\mathrm{m}$ from the ground surface - a zone where human beings spend most of their time. Samples must be taken not closer than $1,0 \mathrm{~m}$ from a pollution source, and $0,5 \mathrm{~m}$ from a person making measurements.

Air flow passing into the hole of a sampling adapter has no obstructions having an effect around a sampling adapter (usually a few meters from buildings, balconies, trees and other obstructions. Besides, although $0,5 \mathrm{~m}$ from the closest building when the place of sampling characters air quality).

The hole of a sampling adapter should not be close to a pollution source because of entirely pollutants get into the hole without mixing with ambient air.

The hole in a sampling adapter should be set up so that exhausted air could not get back into the sampling hole.

Measurements are made in strings, not less than three strings at each point. The meter must be calibrated before and after each measuring string.

Concentration of PM at one of the most bustling crossroads (Ozas and Gelvonai str) of Vilnius city was measured to estimate and compare the results of the mentioned methods and evaluate suitability for measuring very low PM concentrations. Measurements were made in November.

Air was sampled for $20 \mathrm{~min}$ at a different air-flow velocity $(1 \mathrm{l} / \mathrm{min}, 2 \mathrm{l} / \mathrm{min}, 3 \mathrm{l} / \mathrm{min}, 5 \mathrm{l} / \mathrm{min}$ and $10 \mathrm{l} /$ min) for each sampling. Setting of measuring points was chosen as shown in Fig 3, because the place at the crossroad and around it is open, and the road is straight. 

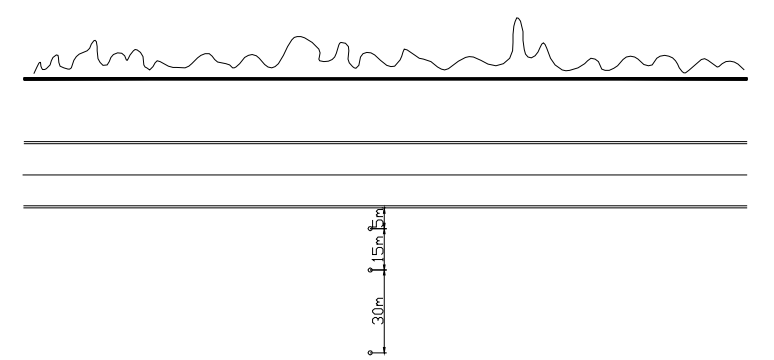

Fig 3. Setting of measuring points for straight road

Measurements were made in the middle of the crossroad (traffic island) and at $5 \mathrm{~m}, 20 \mathrm{~m}$ and $50 \mathrm{~m}$ from the roadside leeward (Fig 3).

\section{Results}

The concentration measurement results for each substance at a different airflow velocity are illustrated in graphs. Concentration of wood PM at a different airflow velocity measured with the help of the mass and optical methods is given in Fig 4.

As it is seen from the graph, concentration of wood PM changes with fluctuations of the airflow. PM concentrations slightly change with increase in the airflow. The change of the concentration found with the help of the mass method is higher, while that found with the help of the optical method is more consistent. When the dusty airflow is $11 / \mathrm{min}$, wood PM concentration measured with the help of the mass and optical methods differs to the greatest extent - on the average by $2,9 \mathrm{mg} / \mathrm{m}^{3}$ (it gives $4,6 \%$ difference). The nearest results are reached when the dusty airflow velocity is $5 \mathrm{l} /$ $\mathrm{min}$, then the difference is $0,2 \mathrm{mg} / \mathrm{m}^{3}$ (only $0,3 \%$ difference). Concentrations measured with the help of the optical method are higher.

PM concentrations must be the same when recalculated by a formula, though the airflow velocity is bigger, but because of a bigger airflow velocity more particles with bigger diameter are sampled.

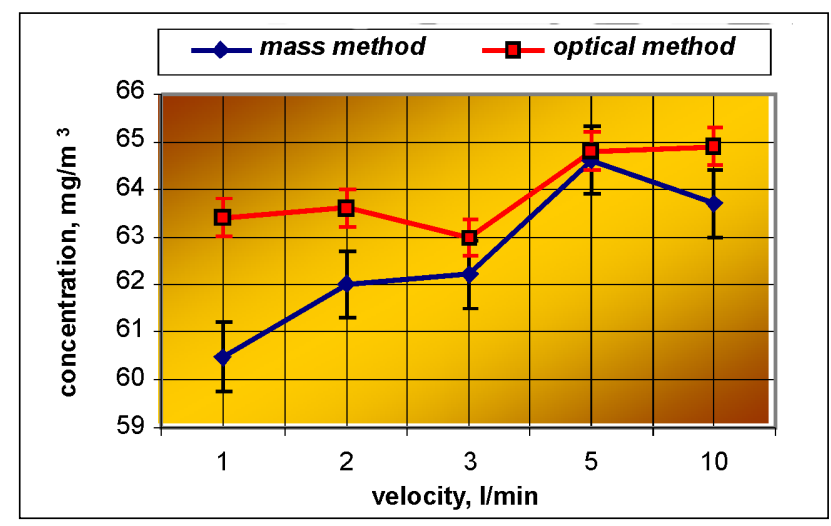

Fig 4. Concentration of wood PM at different airflow velocity measured by mass and optical methods
The total change in the concentration of wood PM is higher when measured with the help of the mass method than that when measured with the help of the optical method. Measuring with the help of the mass method, the concentration difference is $4,1 \mathrm{mg} / \mathrm{m}^{3}$ when sucking air flow at a velocity from $11 / \mathrm{min}$ to $10 \mathrm{l} / \mathrm{min}$, while measuring with the help of the optical method the difference is $1,9 \mathrm{mg} / \mathrm{m}^{3}$. An average coefficient of discrepancy of wood PM concentration when measuring with the help of the mass and optical methods is 0,979 . The error mean-square $\sigma_{\mathrm{x}}$ when measuring with the help of the mass method is 0,712 , and it is 0,384 when measuring with the help of the optical method.

Concentration of cement PM at a different airflow velocity measured with the help of the mass and optical methods is given in Fig 5.

As it is seen from the graph, concentration of cement PM increases with increase in the airflow. When the dusty airflow is $1 \mathrm{l} / \mathrm{min}$, the cement PM concentration measured with the help of the mass and optical methods differs to the greatest extent - on the average by $1,4 \mathrm{mg} / \mathrm{m}^{3}$ (about 2,6\%). The nearest results are reached when the dusty airflow velocity is $5 \mathrm{l} / \mathrm{min}$, then the difference is $0,2 \mathrm{mg} / \mathrm{m}^{3}$ (only $0,35 \%$ ). Concentrations measured with the help of the optical method are higher.

Measuring the concentration of PM with the help of the mass method, the concentration difference is $2,4 \mathrm{mg} / \mathrm{m}^{3}$ when sucking air flow at a velocity from $1 \mathrm{l} / \mathrm{min}$ to $10 \mathrm{l} / \mathrm{min}$, while measuring with the help of the optical method the difference is $2,2 \mathrm{mg} / \mathrm{m}^{3}$. An average discrepancy of cement PM concentration, when measuring with the help of the mass and optical methods, is 0,983 . The error mean-square $\sigma_{x}$, when measuring with the help of the mass method, is 0,489 , and it is 0,402 , when measuring with the help of the optical method.

Concentration of quartz sand PM at different airflow velocity measured with the help of the mass and optical methods is given in Fig 6.

As it seen from the graph, concentration of quartz

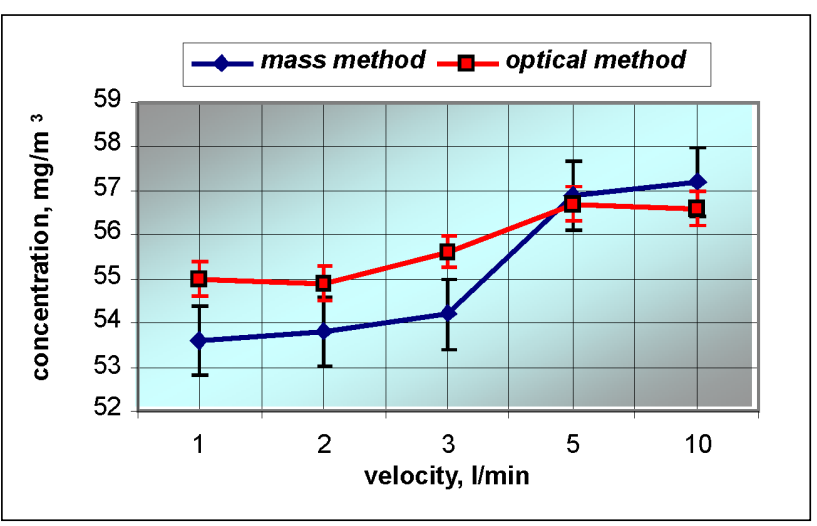

Fig 5. Concentration of cement $P M$ at different airflow velocity measured by mass and optical methods 
sand PM increases with increase in the airflow. Increase in the airflow velocity results in greater intake of bigger particles, thus the concentration of dust slightly increases. When the dusty airflow is $2 \mathrm{l} / \mathrm{min}$, the quartz sand PM concentration measured with the help of the mass and optical method differs to the greatest extent - on the average by $0,8 \mathrm{mg} / \mathrm{m}^{3}$ (about $1,56 \%$ ). The nearest re-

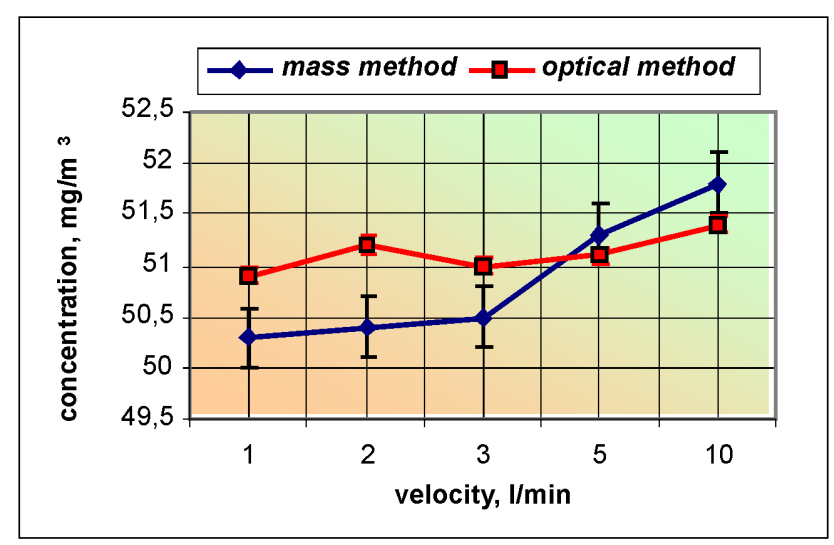

Fig 6. Concentration of quartz sand PM at different airflow velocity measured by mass and optical methods

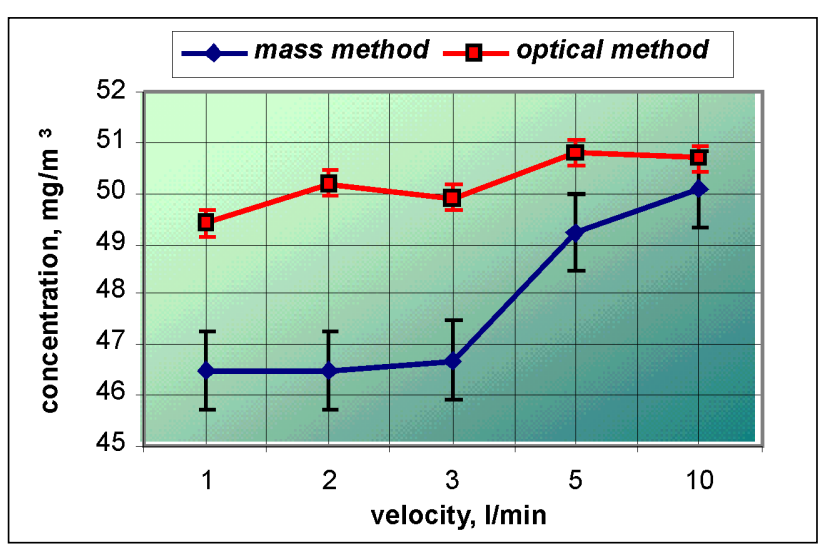

Fig 7. Concentration of metal PM at different airflow velocity measured by mass and optical methods

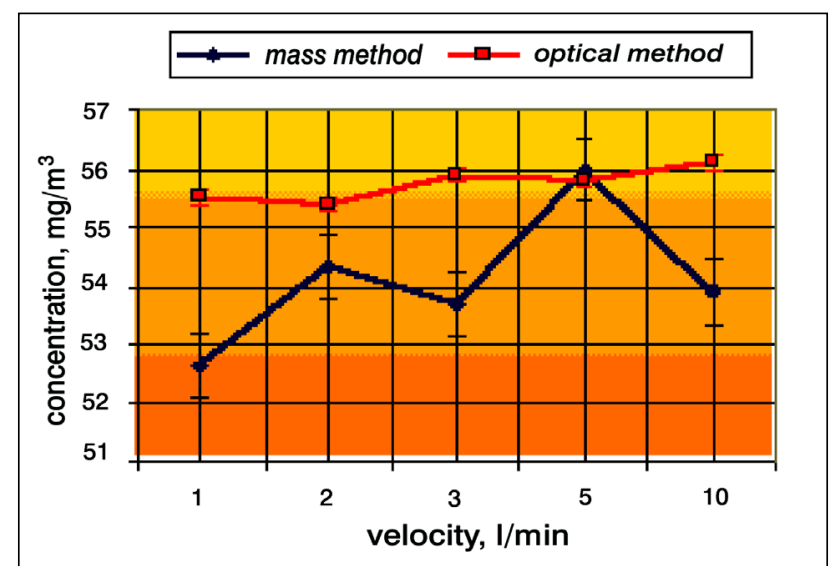

Fig 8. Concentration of clay PM at different airflow velocity measured by mass and optical methods sults are reached when the dusty airflow velocity is $5 \mathrm{l} / \mathrm{min}$, then the difference is only $0,2 \mathrm{mg} / \mathrm{m}^{3}$ (only $0,39 \%)$.

The total change in the concentration of quartz sand PM is higher when measured with the help of the mass method than that when measured with the help of the optical method.

When measuring the concentration of PM with the help of the mass method, the concentration difference is $1,5 \mathrm{mg} / \mathrm{m}^{3}$ when sucking airflow at a velocity from $1 \mathrm{l} / \mathrm{min}$ to $10 \mathrm{l} / \mathrm{min}$, while measuring with the help of the optical method the difference is $0,5 \mathrm{mg} / \mathrm{m}^{3}$. There the values of measured concentration are steadier because the dispersive content of quartz sand is steadier than wood or cement particles [10]. An average coefficient of discrepancy of quartz sand PM concentration, when measuring with the help of the mass and optical methods, is 0,995 . The error mean-square $\sigma_{x}$, when measuring with the help of the mass method, is 0,294 , and it is 0,086 when measuring with the help of the optical method.

Concentration of metal PM at a different airflow velocity measured with the help of the mass and optical methods is given in Fig 7.

As it is seen from the graph, concentration of metal PM changes with the fluctuations of the airflow, ie it slightly increases with increase in the airflow. The change of metal PM concentration found with the help of the mass method is higher, while that found with the help of the optical method is more consistent. When the dusty airflow is $2 \mathrm{l} / \mathrm{min}$, the metal PM concentration measured with the help of the mass and optical methods differs to the greatest extent - on the average by $3,7 \mathrm{mg} / \mathrm{m}^{3}$ (about $7,37 \%$ ). The nearest results are reached when the dusty airflow velocity is $10 \mathrm{l} / \mathrm{min}$, then the difference is $0,6 \mathrm{mg} / \mathrm{m}^{3}$ (only $1,18 \%$ ). The concentration values measured with the help of the optical method are higher.

As in other cases, the total change in the concentration of metal PM is higher, when measured with the help of the mass method, than that, when measured with the help of the optical method. It is particularly seen in this case because the relative mass and sedimentation of metal particles is the biggest.

When measuring the concentration of PM with the help of the mass method, the concentration difference is $3,6 \mathrm{mg} / \mathrm{m}^{3}$ when sucking airflow at a velocity from $1 \mathrm{l} / \mathrm{min}$ to $10 \mathrm{l} / \mathrm{min}$, while measuring with the help of the optical method the difference is $1,4 \mathrm{mg} / \mathrm{m}^{3}$. An average discrepancy of wood PM concentration, when measuring with the help of the mass and optical methods, is 0,952 . The error mean-square $\sigma_{\mathrm{x}}$, when measuring with the help of the mass method, is 0,769 , and it is 0,259 , when measuring with the help of the optical method.

Concentration of clay PM at a different airflow velocity measured with the help of and optical methods is given in Fig 8.

The change of the particle concentration found with the help of the mass method is higher, while that found 
with the help of the optical method is more consistent. When the dusty airflow is $11 / \mathrm{min}$, the clay PM concentration measured with the help of the mass and optical methods differs to the greatest extent - on the average by $2,9 \mathrm{mg} / \mathrm{m}^{3}$ (about $5,23 \%$ ). The nearest results are reached, when the dusty airflow velocity is $5 \mathrm{1} / \mathrm{min}$, then the difference is $0,2 \mathrm{mg} / \mathrm{m}^{3}$ (only $0,36 \%$ ).

When measuring the concentration of PM with the help of the mass method, the concentration difference is $3,4 \mathrm{mg} / \mathrm{m}^{3}$, when sucking airflow at a velocity from $1 \mathrm{l} / \mathrm{min}$ to $10 \mathrm{l} / \mathrm{min}$, while measuring with the help of the optical method the difference is $0,7 \mathrm{mg} / \mathrm{m}^{3}$. An average discrepancy of clay PM concentration, when measuring with the help of the mass and optical methods, is 0,971 . The error mean-square $\sigma_{x}$, when measuring with the help of the mass method, is 0,522 , and it is 0,129 , when measuring with the help of the optical method.

Concentration of charcoal PM at a different airflow velocity measured with the help of the mass and optical methods is given in Fig 9.

The change of measured charcoal PM concentration value has similar tendencies as cement PM concentration. The smaller is dusty airflow velocity the less is measured concentration of charcoal found with the help of the mass method is higher than concentration found with the help of the optical method. When the dusty airflow is $1 \mathrm{l} / \mathrm{min}$ and $10 \mathrm{l} / \mathrm{min}$, the charcoal PM concentration measured with the help of the mass and optical methods differs to the greatest extent - on the average by $1,25 \mathrm{mg} / \mathrm{m}^{3}$ (about 2,0\%). The nearest results are reached when the dusty airflow velocity is $51 / \mathrm{min}$, then the difference is $0,1 \mathrm{mg} / \mathrm{m}^{3}$ (only $0,16 \%$ ).

When measuring the concentration of PM with the help of the mass method, the concentration difference is $3,2 \mathrm{mg} / \mathrm{m}^{3}$ when sucking airflow at a velocity from $1 \mathrm{l} / \mathrm{min}$ to $10 \mathrm{l} / \mathrm{min}$, while measuring with the help of the optical method the difference is $0,7 \mathrm{mg} / \mathrm{m}^{3}$. An average discrepancy of charcoal PM concentration when measuring with the help of the mass and optical methods is 0,997 . The error mean-square $\sigma_{\mathrm{x}}$, when measuring with the help of the mass method is 0,540 , and it is 0,137 when measuring with the help of the optical method.

Concentration of hard PM at a different airflow velocity measured with the help of the mass and optical methods at the middle of the crossroad is given in Fig 10.

The change of the concentration found with the help of the mass method is higher, while that found with the help of the optical method is more consistent. When the dusty airflow is $2 \mathrm{l} / \mathrm{min}$ and $10 \mathrm{l} / \mathrm{min}$ the hard PM concentration measured with the help of the mass and optical methods differs to the greatest extent - on the average by $0,14 \mathrm{mg} / \mathrm{m}^{3}$ (about $36,8 \%$ ). The nearest results are reached when the dusty airflow velocity is $51 / \mathrm{min}$, then the difference is $0,16 \mathrm{mg} / \mathrm{m}^{3}$ (only $33,3 \%$ ).

The total change in the concentration of hard PM is higher, when measured with the help of the mass method, than that, when measured with the help of the optical method. Measuring the concentration of hard PM with the help of the mass method, the concentration difference is $0,14 \mathrm{mg} / \mathrm{m}^{3}$ when sucking at a velocity from $1 \mathrm{l} / \mathrm{min}$ to $10 \mathrm{l} / \mathrm{min}$, while measuring with the help of the optical method the difference is $0,12 \mathrm{mg} / \mathrm{m}^{3}$. An average discrepancy of hard PM concentration, when measuring with the help of the mass and optical methods is 0,730 . The error mean-square $\sigma_{x}$, when measuring with the help of the mass method is 0,171 , and it is 0,051 , when measuring with the help of the optical method.

Concentration of hard PM at a different airflow velocity, measured with the help of the mass and optical methods at $5 \mathrm{~m}$ from the roadside, is given in Fig 11.

When the dusty airflow is $2 \mathrm{l} / \mathrm{min}$ and $10 \mathrm{l} / \mathrm{min}$ the hard PM concentration measured with the help of the mass and optical methods differs to the greatest extent on the average by $0,12 \mathrm{mg} / \mathrm{m}^{3}$ and $0,15 \mathrm{mg} / \mathrm{m}^{3}$ (about $31,6 \%$ and $33,3 \%$ ). The nearest results are reached when the dusty airflow velocity is $51 / \mathrm{min}$, then the difference is $0,06 \mathrm{mg} / \mathrm{m}^{3}$ (only $12,8 \%$ ).

The total change measuring the concentration of hard PM with the help of the mass method, the concentration difference is $0,15 \mathrm{mg} / \mathrm{m}^{3}$ when sucking airflow at a velocity from $1 \mathrm{l} / \mathrm{min}$ to $10 \mathrm{l} / \mathrm{min}$, while measuring

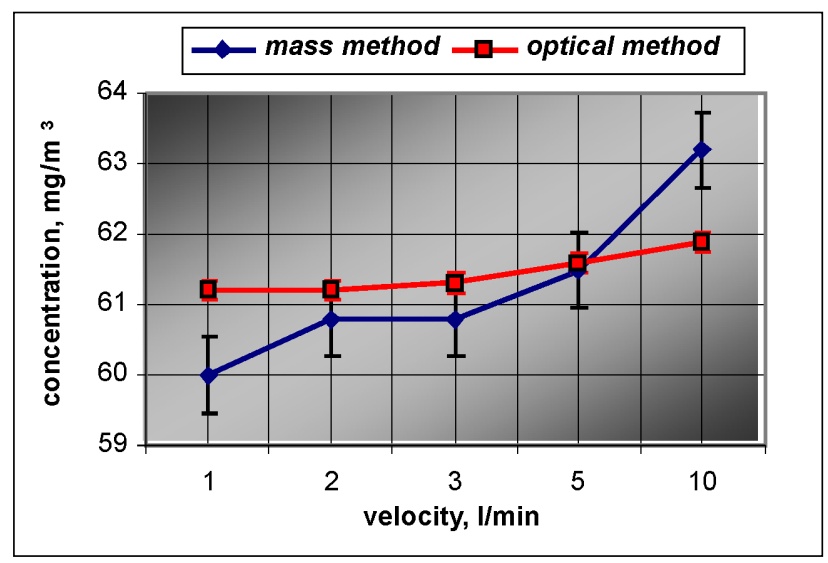

Fig 9. Concentration of charcoal PM at different airflow velocity measured by mass and optical methods

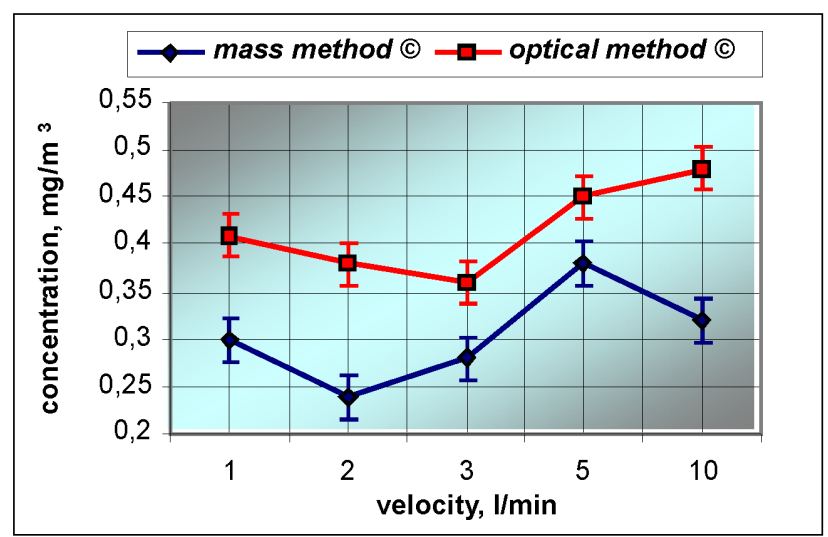

Fig 10. Concentration of hard PM at different airflow velocity measured by mass and optical methods in the middle of crossroad 


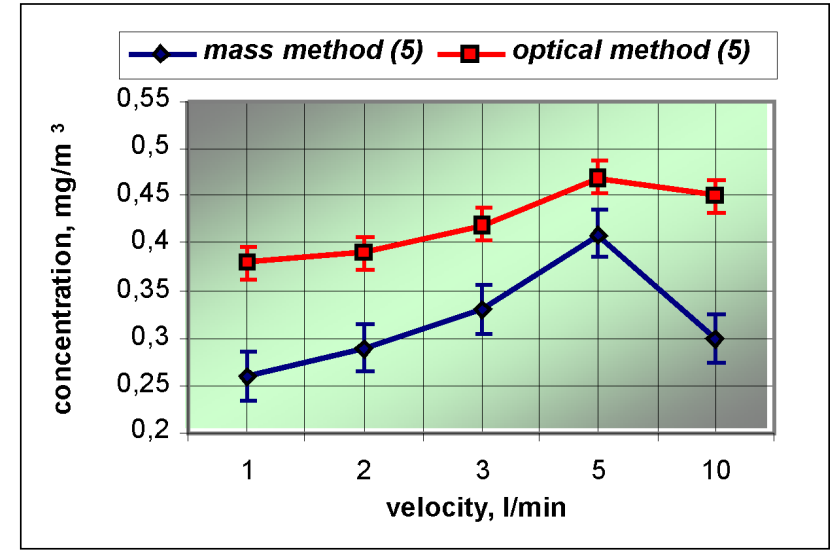

Fig 11. Concentration of hard $\mathrm{PM}$ at different airflow velocity measured by mass and optical methods at $5 \mathrm{~m}$ from roadside

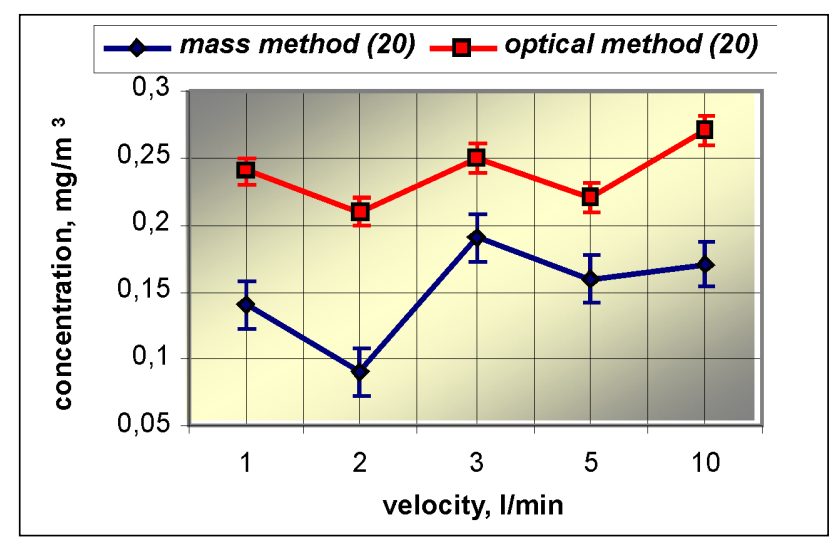

Fig 12. Concentration of hard PM at different airflow velocity measured by mass and optical methods at $20 \mathrm{~m}$ from roadside

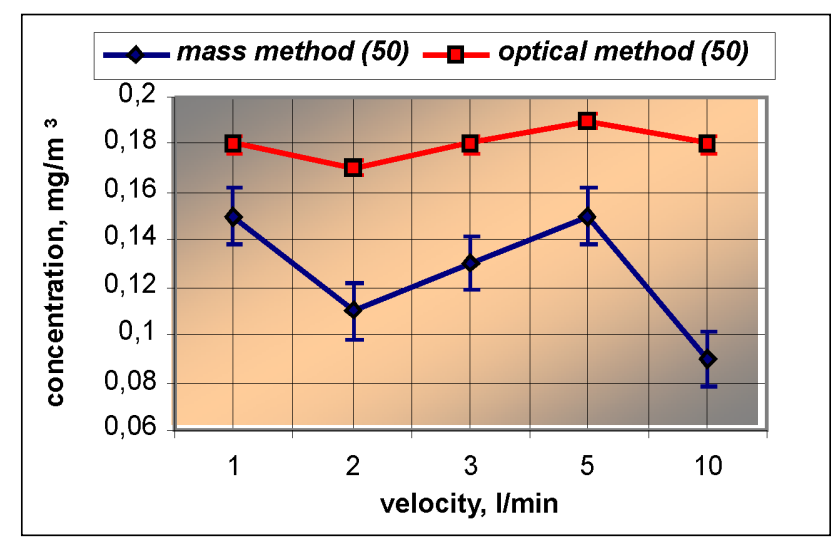

Fig 13. Concentration of hard $P M$ at different airflow velocity measured by mass and optical methods at $50 \mathrm{~m}$ from roadside

with the help of the optical method the difference is 0,09 $\mathrm{mg} / \mathrm{m}^{3}$. An average discrepancy of hard particulate concentration, when measuring with the help of the mass and optical methods is 0,751 . The error mean-square $\sigma_{x}$, when measuring with the help of the mass method, is 0,026 , and it is 0,017 , when measuring with the help of the optical method.
Concentration of hard PM at different airflow velocity measured with the help of the mass and optical methods at $20 \mathrm{~m}$ from the roadside is given in Fig 12 .

Just like in the above-mentioned cases, increase in the airflow velocity results in greater intake of bigger hard PM, thus the hard PM concentration slightly increases. When the dusty airflow is $21 / \mathrm{min}$, the hard PM concentration measured with the help of the mass and optical methods differs to the greatest extent - on the average by $0,12 \mathrm{mg} / \mathrm{m}^{3}$ (about $57,1 \%$ ). The nearest results are reached when the dusty airflow velocity is $3 \mathrm{l} / \mathrm{min}$ and $5 \mathrm{l} / \mathrm{min}$, then the difference is $0,06 \mathrm{mg} / \mathrm{m}^{3}$ (only 24,0\% and 27,3\%).

The total change measuring the concentration of hard PM with the help of the mass method, the concentration difference is $0,10 \mathrm{mg} / \mathrm{m}^{3}$ when sucking airflow at a velocity from $1 \mathrm{l} / \mathrm{min}$ to $10 \mathrm{l} / \mathrm{min}$, while measuring with the help of the optical method the difference is $0,06 \mathrm{mg} / \mathrm{m}^{3}$. An average discrepancy of hard PM concentration, when measuring with the help of the mass and optical methods is 0,626 . The error mean-square $\sigma_{x}$ when measuring with the help of the mass method, is 0,017 , and it is 0,011 , when measuring with the help of the optical method.

Concentration of hard PM at different airflow velocity measured with the help of the mass and optical methods at 50 meters from the roadside is given in Fig 13.

When the dusty airflow is $10 \mathrm{l} / \mathrm{min}$ the PM concentration measured with the help of the mass and optical methods differs to the greatest extent - on the average by $0,09 \mathrm{mg} / \mathrm{m}^{3}$ (about 50,0\%). The nearest results are reached when the dusty airflow velocity is $5 \mathrm{l} / \mathrm{min}$, then the difference is $0,04 \mathrm{mg} / \mathrm{m}^{3}(21,1 \%)$.

The total change measuring the concentration of hard PM with the help of the mass method, the concentration difference is $0,06 \mathrm{mg} / \mathrm{m}^{3}$ when sucking airflow at a velocity from $1 \mathrm{l} / \mathrm{min}$ to $10 \mathrm{l} / \mathrm{min}$, while measuring with the help of the optical method the difference is $0,02 \mathrm{mg} / \mathrm{m}^{3}$. An average discrepancy of hard PM concentration, when measuring with the help of the mass and optical methods is 0,698 . The error mean-square $\sigma_{\mathrm{x}}$, when measuring with the help of the mass method is 0,011 , and it is 0003 , when measuring with the help of the optical method.

In the given graphs we can see that fluctuation of PM concentrations measured with the help of the mass and optical methods are similar. Hard PM concentrations measured by the optical method are higher or less proportional to PM concentrations measured with the help of the mass method.

Only in the middle of the crossroad (Fig 3) concentrations of hard PM measured with the help of the optical method are less and concentrations measured with the help of the mass method are higher, when the airflow velocity is $3 \mathrm{l} / \mathrm{min}$.

In all the cases, when the airflow velocity is $10 \mathrm{l} /$ min, the biggest discrepancy of PM concentrations mea- 
sured with the help of the optical and mass methods is seen.

\section{Conclusions}

1. Concentrations of PM measured with the help of the optical method are higher than those measured with the help of the mass method.

2. The nearest results of PM concentrations, measured with the help of the optical and mass methods, were obtained when the airflow velocity was $5 \mathrm{l} / \mathrm{min}$. It is conditioned by the airflow velocity when more particles set on the filter what gives better conditions to decrease the error.

3. In the case of a different flow of dusty air, the closest measuring results, when measuring with the help of the optical and mass methods, are obtained when measuring concentrations of charcoal. An average difference in the concentrations is $0,70 \mathrm{mg} / \mathrm{m}^{3}$. An average coefficient of discrepancy of PM concentration is 0,997 . The error mean-square $\sigma_{x}$, when measuring with the help of the mass method, is 0,540 , and it is 0,137 , when measuring with the help of the optical method.

4. In the case of a different flow of dusty air, the highest discrepancy of measuring results, when measuring with the help of the optical and mass methods, is obtained, when measuring concentrations of metal PM. An average difference in the concentrations is $2,4 \mathrm{mg} /$ $\mathrm{m}^{3}$. An average coefficient of discrepancy of PM concentration is 0,952 . The error mean-square $\sigma_{x}$, when measuring with the help of the mass method is 0,769 , and it is 0,259 when measuring with the help of the optical method.

5. The closest measuring results, when measuring at a crossroad, are obtained at $5 \mathrm{~m}$ from the road with the help of the optical and mass methods, when measuring concentrations of hard PM. An average coefficient of discrepancy of hard PM concentration is 0,751 . The error mean-square $\sigma_{x}$, when measuring with the help of the mass method is 0,026 , and it is 0,017 when measuring with the help of the optical method.

6 . The most different measuring results, when measuring at a crossroad, are obtained at $20 \mathrm{~m}$ from the road with the help of the optical and mass methods, when measuring concentrations of hard PM. An average coef- ficient of discrepancy of hard PM concentration is 0,626. The error mean-square $\sigma_{x}$, when measuring with the help of the mass method is 0,017 , and it is 0,011 when measuring with the help of the optical method.

\section{References}

1. Baltrènas, P.; Kaulakys, J. Methods and devices of technosphere dusty control (Методы и приборы контроля запыленности техносферы). Vilnius: Technika, 1994. 208 p. (in Russian).

2. Baltrènas, P.; Bakas, A.; Masilevičius, R. Investigation of dust dispersion exhausted to atmosphere from boiler-house stoked by wood. Journal of Environmental Engineering and Landscape Management (Aplinkos inžinerija), Vol VII, No 4. Vilnius: Technika, 1999, p 173-178 (in Lithuanian).

3. Baltrènas, P.; Kaziukonienè, D.; Kvasauskas, M. Air pollution at parking-lots of Vilnius. Journal of Environmental Engineering and Landscape Management, Vol XII, No 1. Vilnius: Technika, 2004, p 38-43.

4. Baltrènas, P.; Staknytè, D.; Vaišis, V. Experimental investigations of filtration foam, designed air filtering. Journal of Environmental Engineering and Ladscape Management, Vol XI, No 4. Vilnius: Technika, 2003, p 133-140.

5. Baltrènas, P.; Vasarevičius, S.; Masilevičius, R.; Petraitis, E. Atmosphere protection in heating energetic (Atmosferos apsauga šiluminèje energetikoje). Vilnius: Technika, 2003. 196 p. (in Lithuanian).

6. Baron P.; Willeke K. Aerosol measurement. New York: Wiley Intersience Publishers, 2001. 52 p.

7. Quilliam JH. Isocinetic sampling. L Mine vent Soc S Afr 10(7):153, 1994. 26 p.

8. Silvestravičiūte, I. optimization of hydrodynamical parameters measurement in ducts. In: Third conference of young scientists of Lithuania "Lithuania without science Lithuania without future". Environmental Protection Engineering. Vilnius: Technika, 2000, p. 168-174.

9. Raymond L. D. Coal mine dust sample processing. Arlington, VA: U.S. Department of labor, Mine Saefty and Health Administration, IR 1249, 1998. 61 p.

10. Skropskaitè, V.; Denafas, G. Estimating of quartz and glass particles as etalon materials and suspension investigations characteristics. In: Sixth conference of young scientists of Lithuania "Lithuania without science - Lithuania without future". Environmental Protection Engineering. Vilnius: Technika, 2003. p 168-174.

\section{EKSPERIMENTINIAI DALELIŲ KONCENTRACIJŲ TYRIMAI TAIKANT SVORINI IR OPTINI METODUS}

\section{P. Baltrėnas, M. Kvasauskas}

$\mathrm{S}$ a $\mathrm{n} \mathrm{tr}$ a u k a

Kietujų dalelių (KD) koncentracijoms matuoti naudojami skirtingos konstrukcijos, skirtingais matavimo metodais pagristi prietaisai. Todèl svarbu žinoti jų tikslumą. Matavimai buvo atlikti pripažintu ir plačiai taikomu svoriniu bei kartu optiniu metodu. Tyrimams naudotos dažniausiai technologiniuose procesuose pasitaikančios medžiagos: medienos dalelès, cementas, kvarcinis smèlis, metalo dalelès, atsirandančios šlifavimo procese, molio ir medžio anglies dalelès. Taip pat buvo išmatuotos KD koncentracijos prie vienos iš judriausių Vilniaus sankryžų. Siekta patikrinti prietaisų ir metodų tinkamumą matuoti labai mažas dalelių koncentracijas. Darbe pateikti matavimo rezultatai ir paklaidos, palyginami koeficientai, rodantys matavimo skirtingais prietaisais ir metodais skirtumus.

Raktažodžiai: svorinis metodas, optinis metodas, kietosios dalelès (KD). 
Pranas BALTRÉNAS. Dr Habil, Prof and head of Dept of Environmental Protection, Vilnius Gediminas Technical University (VGTU), Sauletekio al. 11, LT-10223 Vilnius-40, Lithuania. E-mail aak@ap.vtu.lt.

Doctor Habil of Science (air pollution), Leningrad Civil Engineering Institute (Russia), 1989. Doctor of Science (air pollution), Ivanov Textile Institute (Russia), 1975. Employment: Professor (1990), Associate Professor (1985), senior lecturer (1975), Vilnius Civil Engineering Institute (VISI, now VGTU). Publications: author of 13 monographs, 24 study-guides, over 320 research papers and 67 inventions. Honorary awards and membership: prize-winner of the Republic of Lithuania (1994), a corresponding Member of the Ukrainian Academy of Technological Cybernetics, a full Member of International Academy of Ecology and Life Protection. Probation in Germany and Finland. Research interests: air pollution, pollutant properties, pollution control equipment and methods.

Mindaugas KVASAUSKAS. Master student (environmental protection engineering), Dept of Environmental Protection, Vilnius Gediminas Technical University (VGTU), Sauletekio al. 11, LT-10223 Vilnius-40, Lithuania. E-mail:. aak@ap.vtu.lt

Bachelor of Science (environmental engineering), VGTU, 2003. Publications: author of 2 research papers. Research interests: environmental protection, pollution prevention. 